\title{
Developing Communicative Competence of ESL Learners through Learning Strategies
}

\author{
Purna Bahadur Kadel
}

\begin{abstract}
Learning strategies are special behaviors and actions which are employed to develop communicative competence of learners (Oxford, 1990). Second language learners can communicate their ideas, feelings, and emotions through learning strategies: cognitive, metacognitive, memory, social, affective etc. as well as communicative strategies in the process of developing communicative competence. Learning strategies and communicative strategies work as a panacea to develop communicative competence. The researcher conducted an exploratory research through survey to collect data using questionnaire, semi-structured interview and classroom observation to find out the existing learning strategies in developing speaking skills and to discover the attitude of secondary level teachers towards learning strategies and communicative strategies in developing communicative competence of learners. He selected 30 secondary level teachers as sample population of the study. The findings of the study were: a) the teachers did not use collaborative learning and scaffolding techniques to help the learners develop speaking skills, b) they were unable to employ collaborative learning, group discussion, and peer talking owing to overcrowded classes and time-constraint; most of the teachers taught speaking skill without using language functions, c) there is positive attitude of secondary level teachers towards learning strategies and communicative strategies to develop communicative competence of learners.

Key words: learning strategies, self-regulated, cognitive, metacognitive, compensate, multidimensional, milestone, communicative task, communicative strategies, collaborative learning, motor-perceptive skills, paramount importance
\end{abstract}

\section{Background of the Study}

Communicative competence and performance are hardly practised during the classroom interaction despite the fact that they are prescribed in the syllabus. Listening and speaking skills are primary whereas reading and writing skills are secondary. In the past, reading and writing skills were considered useful rather than listening and speaking skills. Communicative tasks entail comprehending, interpreting, interacting, discussing etc. The communicative tasks are communicative-oriented whereas noncommunicative tasks focus only on the exercises of grammar. The mastery over speaking skill is essential to communicate ones' feeling, emotions, and ideas to others. Learning strategies play a crucial role to develop communicative competence without which interpersonal interaction cannot be launched properly.

If the learners develop their speaking skills, they can attain communicative competence. So speaking skill and 
communicative competence should have deep relationship with each other to enhance second language learning. The role of speaking is of paramount importance to facilitate the learners in enhancing communicative competence.

Learning to speak a foreign language requires more knowledge and skill than knowing its linguistic rules. The speakers should have mastery over both linguistic knowledge and language skills in order to develop their speaking skills. The knowledge of language refers to competence in grammar, vocabulary, and pronunciation whereas the knowledge of language skills is related to interactive and negotiation skills which help accomplish communicative activities successfully. The speakers can attain the language skills through rigorous practice, role play, simulation, narrative, descriptive, instructive, comparative, and decision making activities.

Most of the students who have passed from government-aided schools have very poor communicative competence due to the lack of trained competent teachers implementing learning strategies among learners.

Bygate (1987) argues speaking as a skill which is made up of two skills: motorperceptive skills and interactive skills. Motor-perspective skill refers to perceiving, recalling, and articulating in the correct pronunciation and structures of the language. He argues that "this is relatively superficial aspect of skill which is a bit like learning how to manipulate the controls of a car on a deserted piece of road far from the flow of normal traffic. It is the contextfree kind of skill.... (p. 5)."

The role of motor-perceptive skill is of paramount importance to develop communicative competence of the learners.

\section{Statement of the Problem}

Communicative competence is essential for learners to interact with peers and to have query with the teachers in the class to clarify the ambiguous stuff in the class. The pass outs from government-aided schools have very poor communicative competence owing to so many factors, such as inadequate teaching learning materials, lack of adequate teaching methods, strategies and techniques, lack of professionally sound teachers, political interference etc. The adequate learning strategies have not been employed in the English classroom in most of the government-aided schools despite the fact that most of the teachers are more qualified than in private schools of Nepal. However, the teaching and learning activities have not been running smoothly vis-à-vis privately owned schools due to the lack of concrete policy of the government. The SLC graduates from government-aided schools are unable to communicate accurately, fluently and appropriately in comparison with those who have passed out from the private boarding schools. If the teachers are skillful and competent in employing learning strategies and they have positive attitude towards learning strategies of developing communicative competence, the secondary level learners can develop communicative competence properly.

\section{Objectives}

The objectives of this study were:

- to find out the existing learning strategies that are being used at secondary level to enhance communicative competence,

- $\quad$ to find out the attitude of teachers towards using learning strategies to develop communicative skills,

- to suggest some pedagogical implications from this study. 


\section{Research Questions}

- What are the existing learning strategies that the learners employ in the classroom to enhance communicative competence at secondary level?

- What attitude do the ESL teachers have towards using learning strategies to develop communicative skills?

\section{Significance of the Study}

This study would be a building block of knowledge in the field of teaching and learning specifically for teachers. More importantly, the finding of the study would be impetus for professional development of English teachers regarding the role of learning strategies in developing communicative competence. In addition, it would help the syllabus developers, researchers, subject experts, professionals, policy makers, particularly to pre-service and in-service teachers etc.

\section{Review of Related Literature}

Learning strategies are special behaviors and actions which are to be employed to develop communicative competence of learners (Oxford, 1990).

\section{Learning Strategies}

Learning strategies are any behaviors, thoughts or actions that learners adopt in the process of learning. They can succeed to store, integrate, and retrieve new knowledge and skills in the long-term memory for future use through learning strategies. On the other hand, learning strategies help them to be aware of learning process of new information. They help the learners internalize new techniques and skills in enhancing learning proficiency in the target language.

They are also procedures which facilitate the learners to accomplish learning tasks successfully. Any complicated tasks can be solved through learning strategies. In addition, they are very useful to examine whether the learners have administered appropriate learning strategies in the process of learning and whether less successful learners succeed to employ effective learning strategies in their learning.

According to Oxford (1990), there are six types of learning strategies, such as memory strategies, cognitive strategies, compensation strategies, metacognitive strategies, affective strategies, and social strategies. She categorized these strategies under direct and indirect strategies. Memory, cognitive, and compensation strategies are direct strategies whereas metacognitive, affective, and social strategies are indirect strategies.

The taxonomy of learning strategies is presented as below (Chamot and $\mathrm{O}^{\prime}$ Mally 1990, pp. 198-199):

1) Metacognitive Strategies: Some of the metacognitive strategies are given below.

\begin{tabular}{|c|c|}
\hline $\begin{array}{c}\text { Metacognitive } \\
\text { strategies }\end{array}$ & Description \\
\hline $\begin{array}{l}\text { Advance } \\
\text { organisation }\end{array}$ & $\begin{array}{l}\text { Previewing the main ideas and concepts } \\
\text { of the material to be learned, often by } \\
\text { skimming the text for the organising } \\
\text { principle. }\end{array}$ \\
\hline $\begin{array}{l}\text { Advance } \\
\text { preparation }\end{array}$ & $\begin{array}{l}\text { Rehearsing the language needed for an } \\
\text { oral or written task. }\end{array}$ \\
\hline $\begin{array}{l}\text { Organisational } \\
\text { planning }\end{array}$ & $\begin{array}{l}\text { Planning the parts, sequence, and main } \\
\text { ideas to be expressed orally or in } \\
\text { writing. }\end{array}$ \\
\hline $\begin{array}{l}\text { Selective } \\
\text { attention }\end{array}$ & $\begin{array}{l}\text { Attending to or scanning key words, } \\
\text { phrases, linguistic markers, sentences, } \\
\text { or types of information. }\end{array}$ \\
\hline $\begin{array}{l}\text { Self- } \\
\text { monitoring }\end{array}$ & $\begin{array}{l}\text { Checking one's comprehension during } \\
\text { listening or reading or checking one's } \\
\text { oral or written production while it is } \\
\text { taking place. } \\
\text { Self-evaluation } \\
\text { how well one has accomplished a } \\
\text { learning task. }\end{array}$ \\
\hline $\begin{array}{l}\text { Self- } \\
\text { management }\end{array}$ & $\begin{array}{l}\text { Self-management Seeking } \\
\text { or arranging the conditions that help } \\
\text { one learn, such as finding opportunities } \\
\text { for additional language or content } \\
\text { input and practice }\end{array}$ \\
\hline
\end{tabular}

Journal of NELTA, Vol 20 No. 1-2, December 2015 
2) Cognitive Strategies: Cognitive strategies play a vital role in the process of second language learning. Cognitive strategies are presented concisely below:

\begin{tabular}{|l|l|}
\hline Cognitive Strategies & \multicolumn{1}{c|}{ Descriptions } \\
\hline Resourcing & Using reference material such as dictionaries, encyclopedias, or textbooks \\
\hline Grouping & Classifying words, terminology, numbers, or concepts according to their attributes \\
\hline Note taking & Writing down key words and concepts in abbreviated verbal, graphic or numerical forms. \\
\hline Summarising & Making a mental or written summary of information gained through listening or reading \\
\hline Deduction & Applying rules to understand or produce language or solve problems \\
\hline Imagery & $\begin{array}{l}\text { Using visual images to understand and remember new information or to make a mental } \\
\text { representation of a problem }\end{array}$ \\
\hline Auditory representation & $\begin{array}{l}\text { Playing in back of one's mind the sound of a word, phrase, or fact in order to assist } \\
\text { comprehension and recall. }\end{array}$ \\
\hline Elaboration & $\begin{array}{l}\text { Relating new information to prior knowledge, relating different parts of new information to } \\
\text { each other or making meaningful, personal associations with the new information. }\end{array}$ \\
\hline Transfer & Using what is already known about language to assist Comprehension and production \\
\hline Inferencing & $\begin{array}{l}\text { Using information in the text to guess meaning of new items, predict outcomes, or complete } \\
\text { missing parts. }\end{array}$ \\
\hline
\end{tabular}

Source: Chamot \& O’Malley (1990)

\section{3) Social and Affective Strategies:}

Social strategies help the learners to learn through sharing ideas and experiences with their peers and teachers publicly. Likewise, affective strategies help them to cultivate their learning by reducing anxiety, tension, fatigue, and boredom to some extent. There are some affective strategies, such as questioning for clarification, cooperation, and self-talk. In addition, music, songs, rewards, incentives, and self-appraisal are affective strategies which play a vital role to gear up motivation, attitude, and belief towards learning. Affective strategies are essential to brush up intrinsic motivation for enhancing learning.

\begin{tabular}{|l|l|}
\hline $\begin{array}{c}\text { Social and Affective } \\
\text { Strategies }\end{array}$ & \multicolumn{1}{|c|}{ Descriptions } \\
\hline Questioning for clarification & $\begin{array}{l}\text { Eliciting from a teacher or peer } \\
\text { additional explanation, } \\
\text { rephrasing, examples, or } \\
\text { verification }\end{array}$ \\
\hline Cooperation & $\begin{array}{l}\text { Working together with peers to } \\
\text { solve a problem, pool information, } \\
\text { check a learning task, or get } \\
\text { feedback on oral or written } \\
\text { performance }\end{array}$ \\
\hline Self-talk & $\begin{array}{l}\text { Reducing anxiety by using mental } \\
\text { techniques that make one feel to } \\
\text { do the learning task. }\end{array}$ \\
\hline
\end{tabular}

Source: Chamot \& O'Malley (1990)
4) Memory Strategies: Memory strategies are also called mnemonics which plays a vital role to store the knowledge and to retrieve the information from the long term memory. Memory strategies fall into four sets: creating mental linkage, applying images and sounds, reviewing well; and employing actions. Memory strategies are very effective to use metacognitive strategies like paying attention, and affective strategies like reducing anxiety through deep breathing (Oxford, 1990). Memory strategies are needed while ordering things, making association, and reviewing.

5) Compensation Strategies: Compensation strategies enable the learners to use the new language for comprehending and producing language. Compensation strategies are guessing and inferencing using wide variety of linguistic and nonlinguistic clues. They can be categorized into guessing intelligently and overcoming limitations in speaking and writing. Overcoming limitations refers to switching to more languages, getting help, using mime or gesture, avoiding communication partially or totally, selecting topic, coining 
words etc. (Oxford, 1990). In addition, guessing intelligently refers to using linguistic clues and non-linguistic clues.

\section{Purpose of Language Learning Strategies}

The main purposes of learning strategies are enhancing learning, performing special tasks, solving special problem, and making the learners self-directed.

\section{1) Enhancing Learning: Second} language learning is a bit more complicated than first language since second language learners are frequently intervened by their prior knowledge of first language. So second language learning is exclusively conscious learning which cannot be accomplished effectively in the absence of learning strategies. The setting of second language learning can be made natural and subconscious learning through employing appropriate learning strategies.

2) Performing Special Task: Language learning strategies help them to solve cognitively demanding tasks easily. The learners would fail to encounter with problem-solving task without learning strategies. In order to perform special task, the learners should deploy task-appropriate strategies. Particularly, the high proficiency learners are efficient to employ appropriate learning strategies to carry out their tasks (Green \& Oxford, 1995). On the contrary, low proficiency learners cannot grade and employ appropriate learning strategies with tasks accordingly. Language learning strategies make the learners aware of employing different types of strategies viz. top-down, bottom-up, and interactive strategies accordingly (Abbott, 2006).

3) Solving the Specific Problem: Language learning strategies are in vogue in second language learning due to their multidimensional specific plans and procedures to solve specific problems. The second language learners are made ready to diagnose their strengths and weaknesses in learning and thereby managing instructions of learning strategies to encounter learning problems through learning strategies for example, metacognitive strategies are about monitoring learners' own ability and progress of learning second language through using different types of learning strategies. In fact learning strategies make the learners self-regulated and autonomous.

4) Making Self-Regulated and Autonomous Learners: One of the main purposes of language learning strategies is to make them self-regulated. The successful learners usually employ cognitive, metacognitive, and social strategies in developing learning. The learners can be facilitated to be self-directed for successful language learners through employing learning strategies in their learning. There is a significant relationship between learning strategies and self-regulated learners. If the learners adopt some special techniques and procedures of learning strategies to encode and decode the text, they can acquire language skills and linguistic structures effectively.

\section{Communicative Competence}

Hymes (1972) argues that Chomsky's distinction between competence and performance did not pay attention to the aspect of use of language and related issues of appropriacy of an utterance to particular situation. Thus, Hymes (1972) devised the term 'communicative competence' to refer to the language use in social context and appropriate situation. Communicative ability can be developed through linguistic competence, pragmatic competence, intercultural competence, discouse competence, and strategic competence. 


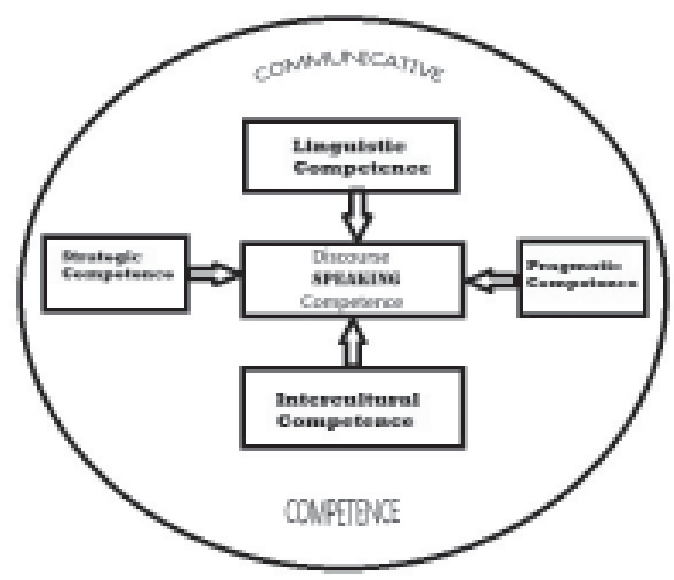

Source: Alice Martinez-Flor, Esther UsoJuan and Eva Alcon, 2006

1) Discourse Competence: MartinezFlor, Uso-Juan and Alcon (2006, p. 147) argue that "the proposed communicative competence framework has at its heart the speaking skill since it is the manifestation of producing spoken discourse and a way of manifestation of the rest of the components." Discourse competence involves speakers' ability to use a variety of discourse markers to attain the unified spoken text. The discourse features are the knowledge of discourse markers. The management of the second language learners must have knowledge of discourse competence to connect the intersentential relationship. In discourse, the role of cohesion and coherence is very paramount to hold the communication in meaningful manner. The speakers should have a substantial knowledge of discourse markers to express their desired ideas and opinions in the process of interaction. The speakers are to be concerned with the linguistic form and appropriacy. Moreover, they should be competent strategically in the course of speaking.

2) Linguistic competence : Linguistic competence comprises grammar, vocabulary, and phonology. The speakers should have a sound knowledge of grammatical structures and vocabulary to produce accurate discourse in speaking. The speakers should have acquired grammatical system and a wider variety of vocabulary in order to make communication successful. Moreover, the speakers must acquire the syntactic and morphological rules of the target knowledge to enhance linguistic competence which in turn corroborate to accelerate speaking skill.

Additionally, the speakers should have the knowledge of suprasegmental, or prosodic features, such as rhythm, stress, intonation etc. for accuracy in pronunciation in the target language.

3) Pragmatic Competence : The speakers should develop pragmalinguistic and sociopragmatic knowledge to develop the pragmatic competence for a successful oral communication. EFL learners should have a broad knowledge in sociolinguistic aspects of target language to communicate appropriately in the society. Language is developed with social conventional norms and rules. So the speakers are to be sensitized with social norms and rules of the target language to make communication interactive since there is symbiotic relation between language and culture. The speakers should be aware of paralinguistic features. Brown, (1994, p. 238) states that "adult second language learners must acquire stylistic adaptability in order to be able to encode and decode the discourse around them correctly". The sociolinguistic knowledge is concerned with style, register, appropriateness and so on.

\section{4) Intercultural Competence :} Intercultural competence refers to the knowledge of how to produce an appropriate spoken discourse within a particular sociocultural context. The 
speakers should have knowledge regarding non-verbal communicative factors and the cultural knowledge to avoid communication breakdown. The speakers should have knowledge of non-verbal communication, such as body language, facial expressions, eye contact etc. to make the spoken discourse successful since paralinguistic, body language, and sociocultural perspective have symbiotic relation with one another.

5) Strategic Competence: Strategic competence embraces speakers' knowledge of both learning and communication strategies. Confirmation check, comprehension check, clarification request, and repetition requests are also the strategies to make oral communication successful.

Learners can enhance speaking proficiency through inferring, predicting, guessing, paraphrasing, circumlocution, repetition, planning and so on. Moreover, they can follow the cognitive, metacognitive, compensation, social, affective, and memory strategies to make the communicative interaction successful and effective. The speakers should have immense knowledge of how to start and how to end the communication with the interlocutors effectively through the use of learning strategies.

\section{Methodology}

The following procedure was adopted to carry out the research addressing the objectives and research questions.

\section{Design}

This is an exploratory study through which the researcher has collected the data using survey method. He has carried out this research qualitatively.

\section{Sample Population and Sampling Procedure}

The researcher has selected 30 secondary level teachers from Kathmandu district for administering questionnaire. Ten secondary schools were selected for collecting data. Three teachers were selected from each school purposively. Out of the 30 teachers, classes of 10 teachers were observed. He selected 30 teachers using purposive non-random sampling procedure. The researcher administered semi-structured interview and informal interview to 10 teachers who were selected randomly regarding the use of learning strategies.

\section{Data Collection Tools}

The researcher used questionnaire, semistructured interview, and classroom observation checklist as tools to collect data to carry out the research. The researcher observed the classes of 10 teachers to find out whether they used learning strategies to develop communicative competence using classroom observation checklist. $\mathrm{He}$ also employed informal interview to collect the data regarding the attitude of teachers towards using learning strategies and existing learning strategies that teachers use in developing communicative competence in the classroom.

\section{Data Collection Procedure}

The researcher administered questionnaire to 30 teachers. Subsequently, he conducted classroom observation of 10 teachers. Furthermore, he gathered the data through informal interview with 5 teachers. 


\section{Analysis of the Data Collected through Questionnaire and Semi- structured Interview}

A majority of respondents stated that most of the learners used memory strategy to develop speaking since the learners felt difficulty to use metacognitive, cognitive, compensation, social and affective strategies. A minority of respondents stated that they prioritize metacognitive, cognitive and compensating strategies to develop communicative competence of learners. A majority of respondents strongly agreed that visual pictures and images help the learners to guess the meaning and encourage discussion with peers and in group regarding the information given in the picture. However, they are unable to teach them through using visual images and pictures to develop communicative performance and competence owing to overcrowded classes and lack of overhead projectors etc in the classes. Most of the respondents agreed that they sometimes asked the students to summarize and convert the text verbally in their own words in the classroom. However, a large number of respondents asserted that they usually do not ask to revise and summarize the lesson verbally after teaching due to the lack of time and reluctance of the students to speak in front of their friends and teachers. There was positive response regarding the guessing of meaning while holding conversation to avoid the breakdown in communication when there is doubt. Approximately, majority of the respondents strongly agreed that collaborative learning and scaffolding help the learners to develop speaking skills; however, they are unable to employ collaborative learning, group discussion, and peer talking due to overcrowded classes and time-constraint. Most of the respondents agreed that practices of carrying out communicative tasks rather than merely focusing on grammar oriented exercises facilitate the learners to develop communicative competence, but they have to teach grammatical forms more than language functions because the textbook contains more grammatical structures than language functions. A majority of the respondents agreed that communicative strategies play a significant role to develop the competencies, such as asking for clarification and repetition, formulaic forms, negotiation of meaning, etc.

\section{Analysis of Data Collected through Classroom Observation Checklist}

From classroom observation, it was found that teachers used lecture method while teaching in the classroom. Most teachers did not help the learners in employing learning strategies due to overcrowded unmanageable classes, lack of modern technology and power in class, and pressure of finishing course in time etc. Most of the teachers help the learners to self-check their utterance before speaking. Most of the learners use dictionary, textbook etc. to find out the meaning of difficult words and to carry out the tasks. They also check their answer before communicating with their peers while talking in the group. They are very careful regarding the accurate use of tense, vocabulary items, and correct use of pronunciation while speaking and before uttering in the class. Most of the learners use memory strategies such as retrieving ideas from the long term memory. The researcher found that most of the learners do not like to work in group and with peers in the classroom. The learners like listening the lectures from teachers passively. Moreover, the teachers are unable to conduct group discussion and peer talking due to the overcrowded class and unmanageable classroom dynamics.

\section{Conclusion}

Language learning strategies are inevitable to develop communicative competence in

$58 \quad$ Journal of NELTA, Vol 20 No. 1-2, $\quad$ December 2015 
the multilingual classroom. The learners can be autonomous and self-regulated learners through the learning strategies. It was found that a majority of teachers used memory strategy to develop speaking strategies. A minority of respondents stated that they use metacognitive, cognitive and compensating strategies to develop communicative competence; for instance, learners learn through guessing the meaning from context; self-evaluation of their learning, and thinking critically . A majority of respondents $(60 \%)$ strongly agreed that visual pictures and images help the learners to develop speaking skills; however they are unable to help them using visual images and pictures to develop speaking skills owing to overcrowded classes and lack of overhead projectors, computer and power supply in the classes. It was revealed that teachers do not use collaborative learning and scaffolding techniques which may help the learners develop speaking skills. More importantly, they are unable to employ collaborative learning, group discussion, and peer talking owing to overcrowded classes and time constraint. Secondary teachers have positive attitude towards learning strategies to develop communicative competence of learners since learning strategies help the learners to learn through peer and group talking, thinking some issues critically, self-monitoring their own pace of learning, and creative production.

\section{References}

Abbott, M. L. (2006). Reading strategies differences in Arabic and Mandarin speaker test performance. Language Learning, Vol. 56(4), 633-670

Brown, H. D. (1994). Principles of language learning and teaching. Englewood Cliffs, NJ: Prentice Hall.

Brown, H. D. (2007). Teaching by Principles: An Interactive Approach to Language
Pedagogy. New York: Pearson Education Inc.

Bygate, M. (1987). Speaking. Oxford: Oxford University Press.

Chamot, A. U. V. and O'Malley, J. M. (1990). Learning Strategies in Second Language Acquisition.Cambridge: Cambridge University Press.

Green, J. M. and Oxford, R. L. (1995). A closer look at learning strategies, L2 proficiency and gender. TESOL Quarterly, Vol. 29(2), 261-297.

Green, J. M. and Oxford, R. L. (1995).A closer look at learning strategies, L2 proficiency and gender. TESOL Quarterly, Vol. 29(2), 261-297.

Hymes, D. (1972). On communicative competence. In Pride, J. B. and J. Holmes (Eds.), Sociolinguistics. Harmondsworth: Penguin.

Martinez-Flor, A., Uso-Juan, E. \& Alcon E. (2006). Towards acquiring communicative competence through speaking. In Alicia Martinez-Flor and Esther uso-Juan (Eds.). Current rends in the development and teaching of the four language skills. New York: Mouton de Gruyter.

Oxford, R. L. (1990). Language Learning Strategies: What every teacher should know?New York: Newbury House/ Harper\& Row.

\section{Author's bio}

Purna Bahadur Kadel teaches at Central Department of English Education, Tribhuvan University. He earned Ph.D in ELT from The English and Foreign Languages University Hyderabad, India. There are half a dozen of articles to his credit in national and international journals. He has presented a number of papers in conferences home and abroad. 


\section{Appendices}

\section{Appendix I}

\section{Questionnaire for the Teachers}

Teachers' profile

Section A

1. Name:

2. Age:

3. Sex:

4. Place of Resident:

5. Name of school presently working at:

6. Academic Qualification:

7. Teaching experience (in years)

1) Level taught:

\section{Section B}

Please tick against appropriate answer below that best suits your choice.

1. Which learning strategies do you adopt while teaching in developing speaking skills?
a) cognitive
b) metacognitive
c) memory
d) compensation
e) social
f) affection

2. Visual images and pictures play significant roles to develop speaking skills of the learners.
a) Strongly Disagree
b) Disagree c) Neutral d)
d) Strongly Agree
E) Agree

3. How often do you ask your students to summarize recently taught text at the end of each lesson?
a) Always B) Often
c) Sometimes
D) rarely
E) Never

4. Guessing of the meaning is very necessary to make the conversation successful and effective.
a) Strongly Disagree b) Disagree c) Neutral d) Strongly Agree E) Agree 
5. The interlocutor/listener should ask question for clarification to avoid the breakdown of conversation.
a) Strongly Disagree
b) Disagree c) Neutral d)
d) Strongly Agree
E) Agree

6. How often do you employ collaborative learning and assisting to develop communicative competence?
a) Always B) Often c) Sometimes
D) rarely
E) Never

7. Do you think that peer talking and group discussions help the learners to enhance their internalizing the meaning and using it properly
a) Yes
b) No

8. Which of the following strategies help the learners to speak in class?
a) The students are rewarded when they speak well.
b) Ask them to explain main theme of the song when they have listened it.
c) Ask them to review the paragraph verbally.

9. The students can develop communicative ability through audio visual movie.
a) Strongly Disagree
b) Disagree
c) Neutral
d) Strongly Agree
E) Agree

10. The students can develop communicative competence through using of language functions contextually rather than focusing on the linguistic structures.
a) Strongly Disagree
b) Disagree
c) Neutral
d) Strongly Agree
E) Agree

11. Do you believe that group discussion and peer talking can develop communicative competence?
a) Yes
b) No

12. Which of following communicative strategies are essential to develop speaking skills?
a) Using fillers
b) asking for clarification
c) adopting formulaic expression
d) using non-verbal expression
e) all of the above

13. Negotiation of meaning between speaker and interlocutor is very impotent to make the interaction meaningful.
a) Strongly Disagree
b) Disagree c) Neutral
d) Strongly Agree
E) Agree

14. The paralinguistic features compensate the speakers to avoid breakdown of communication.
a) Strongly Disagree
b) Disagree c) Neutral
d) Strongly Agree
E) Agree

15. Do you think that learning strategies help to gear up the communicative competence of learners?
a) Yes
b) No 


\section{Appendix II}

\section{Classroom Observation Checklist}

\begin{tabular}{|c|c|c|c|c|c|}
\hline Checklists & Very good & Good & Normal & Poor & Very poor \\
\hline \multicolumn{6}{|l|}{ Well -organized of the ideas } \\
\hline \multicolumn{6}{|l|}{ Self-checking of the utterance of the ideas } \\
\hline \multicolumn{6}{|l|}{$\begin{array}{l}\text { Note-taking and note making to understand } \\
\text { the text in the classroom }\end{array}$} \\
\hline \multicolumn{6}{|l|}{ Use of resources form dictionary, textbooks, Google etc. } \\
\hline \multicolumn{6}{|l|}{$\begin{array}{l}\text { Guess and predict the meaning and ideas contextually } \\
\text { while conversing with the peers }\end{array}$} \\
\hline \multicolumn{6}{|l|}{$\begin{array}{l}\text { Work in groups and with peers to solve the tasks in } \\
\text { the classroom verbally }\end{array}$} \\
\hline $\begin{array}{l}\text { Involve in explaining and analyzing the task with peers } \\
\text { to solve the problem in the classroom }\end{array}$ & & & & & \\
\hline
\end{tabular}

\section{Appendix III}

\section{Questions for semi-structured Interview}

1. Do you use learning strategies to develop speaking skills?

2. Do you believe that visual images and pictures play significant roles to develop speaking skills?

3. How often do you ask to your students to summarize orally at the end of lesson?

4. Do you make the learnersaware clarification questions should be asked to avoid breakdown of communication?

5. Do you believe that peer talking and group discussions help the learner to develop their communicative skills?

6. Do you think that group discussion and collaborative learning avoid shyness, hesitation, and nervousness of the learners? 